\title{
Qualitative analysis of healthcare providers and administrators' perceptions, expectations, barriers, and facilitators towards pharmacists in mental healthcare in Saudi Arabia
}

\author{
Badar Dhehawi A Aldhafeeri \\ Clinical Pharmacy Department, Medical Services-Ministry of Interior, Saudi Arabia
}

\author{
Keywords \\ Pharmacist \\ Pharmacy student \\ Saudi Arabia \\ Qualitative research
}

\section{Correspondence}

Badar Dhehawi A Aldhafeeri

Clinical Pharmacy Department

Medical Services-Ministry of Interior

Saudi Arabia

bdhafeeri@moimsd.gov.sa

\begin{abstract}
Objective: To explore the views and experiences of healthcare providers (HCPs) and their expectations toward pharmacists in mental healthcare, in addition to their acceptance of new pharmacist roles. Barriers and facilitators that are emerging in the process of developing enhanced pharmacist-related roles were also explored. Methods: Qualitative semi-structured face-to-face interviews were conducted with HCPs who had worked in mental health services in Saudi Arabia. The data were thematically analysed using a constant comparison with NVivo software to develop a series of key themes from the interviews. Results: Most HCPs indicated that they rarely interacted with pharmacists. They expected pharmacists to educate both patients and other healthcare workers in the future. Concerns were raised regarding inadequate pharmacy education and lack of clinical training for pharmacists. Conclusion: This study revealed that interactions between HCPs and pharmacists concerning mental health are still limited. A communication strategy for addressing mental health issues should be developed among pharmacists and other HCPs.
\end{abstract}

\section{Introduction}

Recent research has found that an estimated $20 \%$ of people in the world live with a mental disorder or psychological illness, including substance abuse (Charlson et al., 2019). Compared to the rest of the population, this group experiences a significantly reduced average life expectancy between 10.4-15.9 years (Lawrence et al., 2013). No studies to date have examined the prevalence of mental illnesses in the general Saudi Arabia community (Shahab et al., 2017).

The traditional pharmacist's role as a healthcare professional includes preparing and dispensing medications at pharmacies. Such a "traditional" pharmacist does not effectively participate in nontraditional methods of pharmaceutical care, which involve working with patients and other healthcare professionals (HCPs) to optimise medication use and promote health, wellness, and disease prevention (Khan et al., 2020). Recently, pharmacy services have evolved to emphasise patient-centred care, where pharmacists in the healthcare team are required to monitor patient responses to drugs, interpret laboratory tests, enhance medication adherence, refer severe cases to the hospital when appropriate, and provide recommendations concerning the most appropriate medications (Sabry et al., 2014; Rotta, 2015). Pharmacists can help review patient medication regimens, side-effects, drug interactions and educate other healthcare workers to improve patient outcomes and decrease healthcare costs (Alipour et al., 2018). Interprofessional collaborations between doctors, pharmacists, and other HCPs has become a critical element of healthcare, as it could improve patient care and the effectiveness of healthcare delivery (Son et al., 2015).

Further development of patient care services depends on the willingness of HCPs to work with pharmacists and on barriers inhibiting services. Pharmacists often 
experience difficulties integrating into teams due to unclear responsibilities and low HCP confidence in pharmacist abilities (Almazrou et al., 2015). Inadequate education is another barrier (Mekonnen et al., 2018). Pharmacists may be geographically isolated, have limited access to patient records, and lack selfconfidence or experience (Kempen et al., 2020). Finally, a shortage of appropriately trained pharmacists exists (Mekonnen et al., 2018). However, these drawbacks can be overcome. Indeed, pharmacists can be trained to care for people with mental illness effectively, the uptake of pharmacist services can be increased, and pharmacists can be taught skills for counselling this specific population (Mekonnen et al., 2018). Other suggestions include building solid relationships with other HCPs, clarifying responsibilities of team members, and providing practice- and communication-focused training for pharmacists and physicians (Alaqeel \& Abanmy, 2015). Hospital pharmacies can be further promoted by using new technologies (Vermeulen et al., 2014), such as electronic prescription, barcode dispensing, unit-dose distribution systems, and computer-controlled intravenous infusion pumps (UIPumps), as described by McLeod and colleagues (2019).

This study aimed to provide a clear understanding of perceptions and expectations of healthcare providers in Saudi Arabia regarding pharmacy services in mental health settings. This study investigated the perceptions, experiences, and expectations of HCPs, including doctors, pharmacists, nurses, psychologists, and administrators/managers. Potential barriers and facilitators that are emerging in the developing role of pharmacists were also explored.

\section{Methods}

\section{Participants and recruitment}

The study took place at three governmental secondary care mental health services in three different cities (Riyadh, the Eastern Province, and Hafar Albatin) in Saudi Arabia. The hospitals were Al Amal Complex for Mental Health in Riyadh, Mental Hospital in Hafar Albatin, and Al Amal Complex for Mental Health in Dammam within the Eastern Province. These three regions exemplify three different models of pharmacy; therefore, the perspective of HCPs in Riyadh was expected to differ from that of HCPs in the Eastern Province and Hafar Albatin. Riyadh is the political and financial capital and the most populous city of Saudi Arabia, situated in the centre of Saudi Arabia. The Eastern Province is the largest province of Saudi Arabia by area and the centre of the Saudi oil industry. Hafar Albatin is the largest city in Northeastern Saudi Arabia.
The aim was to perform 12-16 interviews or fewer if saturation was reached, for example, when no new patterns or themes emerged during interviews, where saturation was fixed at 14 interviews.

Participants were selected according to the following criteria, all of which had to be fulfilled: 1) HCPs (physicians, pharmacists, nurses, and psychologists) and managers who had coordinated with pharmacists in the past; 2) HCPs who have been associated with providing mental healthcare within Saudi Arabia; 3) HCPs holding practising certifications from The Saudi Arabia Commission for Health Specialties (SCHS); and 4) HCPs willing to take part in an interview and answer questions about perceptions, expectations, barriers, and facilitators toward the role of pharmacists in mental services in Saudi Arabia.

\section{Data collection}

This descriptive and exploratory qualitative study used semi-structured face-to-face interviews with HCPs who might work or did work with pharmacists in mental health settings and follows the consolidated criteria for reporting qualitative research (COREQ) described by Tong and collaborators (2007). The choice of a qualitative study was driven by the fact minimal research has been carried out in Saudi Arabia to ascertain psychiatrists' views on the potential role of pharmacists in mental health. Additionally, a qualitative approach was deemed the most appropriate to reveal relevant themes and learn from participants about their previous experiences and perceptions (Grossoehme, 2014). Qualitative research methods have become frequent in clinical medicine, health services, and policy research, especially mental health services research (Cristancho et al., 2018).

For this study, in-depth semi-structured interviews were used to explore respondent experiences, attributions of meanings, and complex themes (Hadi \& José Closs, 2015; Sawatsky et al., 2019). Using an openended questionnaire in face-to-face interviews, the researcher encouraged participants to answer the questions freely and then reworded and clarified questions as necessary (Hadi \& José Closs, 2015). The key informants had opportunities to explain their perspectives and points of view and to raise their concerns about representing the profession. The interview used a framework for each question (Grossoehme, 2014). The researcher asked additional questions when deemed necessary to uncover new points or understand better participant opinions (Grossoehme, 2014).

A semi-structured interview schedule (Supplementary material) was developed to explore HCPs views on the nature and influence of trust in medication 
management. The General Directorate for Research \& Studies (GDRS) staff in Saudi Arabia sent invitations and participation requirements for the study via email after identifying eligible study participants from the HCP database. One email reminder was sent by the GDRS staff. Written informed consent was obtained from all interviewees before the meeting. Interviews were carried out by a male senior clinical pharmacist with over ten years of experience in Saudi Arabian mental healthcare. The interviewer did not have a personal or professional relationship with any of the participants. Only the participant and researcher were present during interviews. Based on discussions with the study supervisor and piloting the schedule with colleagues, it was anticipated that each interview would last 20 to 25 minutes. The exact start time and location were agreed upon by the researcher and the interviewees.

Participants were free not to answer questions if they chose. Although most health professionals in Saudi Arabia have a high level of English language skills (since most of their education was in English), all interviews were done in Arabic based on the informant's spoken language, with the interview schedule translated into Arabic as needed and double-checked by the researcher. Responses in Arabic were translated into English. Interviews were recorded, and the recordings were transcribed verbatim as supplements to notes made by the researcher during the proceedings. Computer-recorded data were stored on a passwordprotected computer to ensure confidentiality. Research records will be destroyed within six years after study completion. Destruction will be authorised by the principal investigator and carried out in accordance with the relevant authority in Saudi Arabia for the destruction of redundant records.

\section{Data analysis}

Transcripts were analysed line-by-line using colours and comments and then read repeatedly by the researcher to identify key ideas, sentiments, and participant use of analogies and metaphors (Çelik et al., 2020). Meaningful units were condensed according to appropriate themes identified and determined from the researcher's perspective and research questions, and the themes were stratified into categories. Interview transcripts were assessed independently by the research supervisor. Participants were offered the opportunity to read, re-read, and comment on their own transcribed interview (Çelik et al., 2020).

\section{Ethics approval}

The proposal was approved by the University Ethics
Committee (application \#967), the Research and Ethics Committee at the Ministry of Health in the Kingdom of Saudi Arabia (KSA) (IRB Log Number: 16-362E), IRB Registration Number with KACST, KSA (H-01-R-012), IRB Registration Number with OHRP/NIH, USA (IRB00010471), and Approval Number Federal Wide Assurance NIH, USA (FWA00018774).

\section{Results}

Data were collected through qualitative face-to-face, semi-structured interviews with selected mental health HCPs from three localities in Saudi Arabia. The 14 respondents reported their perceptions, views, and beliefs on the topic. Three main themes were identified. To ensure participant confidentiality, hospital affiliations have been referred to as $A, B$, and C throughout the text, with all participants in a hospital having the same code letter.

\section{The role of pharmacists in multidisciplinary teams}

Overall, most participants felt that they rarely interacted with pharmacists in their hospitals, and pharmacists who were only involved in pharmaceutical care services were seen to have no efficacious role in the healthcare team because they merely dispensed medications. For example, Participant 10 (specialist psychiatrist) indicated that: "pharmacists only dispense these drugs and these drugs are written by the physicians, and pharmacist only dispense them."

Some participants felt that because the healthcare team and pharmacists did not interact, the pharmacists were not involved in patient care collaborative efforts. Some participants mentioned the lack of professional communication between pharmacists and healthcare professionals as a barrier to successful collaborations within the care team. Participant 1 (healthcare administrator) clarified: "The pharmacist works in a separate location. So, the pharmacist does not engage with healthcare providers, which causes collaborative problems with the healthcare team."

Regarding the future role of the pharmacist, participants felt that better communication should be established between the pharmacist and the healthcare team, and pharmacists should play a more active role on the wards. Participant 9 (consultant psychiatrist) considered that "regular meetings between the physician and pharmacist should be scheduled with the aim of discussing the expected drugrelated outcomes in the patient". Most participants felt that the pharmacist knows the most about drug actions/interactions. Thus, making policy changes would allow the pharmacist to make recommendations 
within specialised mental health teams, assist the healthcare team in designing drug therapy treatment plans, and enable the team to assess adverse effects, especially in mental health patients. Additional comments by different types of HCPs are shown in Table I.

Table I: Theme 1 - The future role of mental health pharmacists in Saudi Arabia

\begin{tabular}{llll}
\hline $\begin{array}{l}\text { Participant } \\
\text { profession }\end{array}$ & $\begin{array}{l}\text { Participant } \\
\text { ID }\end{array}$ & $\begin{array}{l}\text { Subtheme } 1 \text { comments } \\
\text { The role of pharmacists in a } \\
\text { multidisciplinary team }\end{array}$ & $\begin{array}{l}\text { Subtheme } 2 \text { comments } \\
\text { The role of pharmacists in } \\
\text { directly interacting with } \\
\text { patients }\end{array}$ \\
\hline $\begin{array}{llll}\text { Healthcare } \\
\text { administrator }\end{array}$ & $\begin{array}{l}\text { The pharmacist works in a } \\
\text { separate location (1). }\end{array}$ & $\begin{array}{l}\text { Pharmacists' roles are changing } \\
\text { and tend to be closer to the } \\
\text { services in } \text { mental health } \\
\text { patient (1). } \\
\text { It should remain the physician's } \\
\text { responsibility to warn patients } \\
\text { about adverse drug effects and } \\
\text { discontinue the treatment to } \\
\text { prevent complications (8). }\end{array}$
\end{tabular}

\begin{tabular}{|c|c|c|c|c|}
\hline Registrar & 14 & $\begin{array}{l}\text { I hope to improve the } \\
\text { collaboration between } \\
\text { pharmacists and physicians in the } \\
\text { future. I would like to see } \\
\text { pharmacists participate in ward } \\
\text { rounds with physicians. So, the } \\
\text { pharmacist would perform a } \\
\text { review of drug therapy and help us } \\
\text { reduce potential drug interactions } \\
\text { and adverse effects (14). } \\
\text { Although all members of the } \\
\text { healthcare team interact directly } \\
\text { interact with each other, the } \\
\text { pharmacists are rarely met or } \\
\text { discuss with us (14). }\end{array}$ & & $\begin{array}{l}\text { So, the pharmacist reviews the } \\
\text { dose and side effects, interactions, } \\
\text { and indications for drugs, and the } \\
\text { pharmacist is able to perform } \\
\text { interventions relating to side } \\
\text { effects and reviews patient } \\
\text { medications for drug-drug } \\
\text { interactions. Pharmacists use } \\
\text { pharmacokinetics and } \\
\text { pharmacodynamic principles to } \\
\text { determine the clinical effects of } \\
\text { drug therapy (14). }\end{array}$ \\
\hline $\begin{array}{l}\text { Specialist } \\
\text { psychiatrist }\end{array}$ & 5,10 & $\begin{array}{l}\text { The pharmacist is a member of the } \\
\text { healthcare team, and we need the } \\
\text { pharmacist to improve overall } \\
\text { patient care (5). } \\
\text { The pharmacist only dispenses } \\
\text { these drugs, and these drugs are } \\
\text { written by the physician, and the } \\
\text { [pharmacist only dispenses them } \\
\text { (10). }\end{array}$ & & \\
\hline $\begin{array}{l}\text { Consultant } \\
\text { psychiatrist }\end{array}$ & 9,11 & $\begin{array}{l}\text { It should be regular meeting about } \\
\text { the same patient between the } \\
\text { pharmacist and physician. And } \\
\text { discuss the expected result from } \\
\text { the drug on the patient, selection } \\
\text { of the medication for the same } \\
\text { patient, drug-drug interactions. It } \\
\text { should be a daily interaction, and } \\
\text { it should be complementary (9). }\end{array}$ & $\begin{array}{l}\text { The patient can have an } \\
\text { appointment with the clinical } \\
\text { pharmacist in a private medicine } \\
\text { clinic before the next visit to } \\
\text { evaluate the effect of the drug, } \\
\text { especially if the patients have } \\
\text { long-term conditions (9). } \\
\text { The pharmacist educates and } \\
\text { counsels the patients and the } \\
\text { patients adhere to the treatment } \\
\text { plan (11). }\end{array}$ & $\begin{array}{l}\text { There is no clinical pharmacy in the } \\
\text { hospital (9). }\end{array}$ \\
\hline $\begin{array}{l}\text { Specialist } \\
\text { clinical } \\
\text { psychologist }\end{array}$ & 2 & & $\begin{array}{l}\text { The problem is that pharmacists } \\
\text { do not educate and counsel the } \\
\text { patients. Some participants } \\
\text { highlighted a lack of } \\
\text { communication skills as a } \\
\text { hindrance to effective contact } \\
\text { between pharmacists and patients } \\
\text { (2). }\end{array}$ & $\begin{array}{l}\text { If there is a patient who takes } \\
\text { clozapine, then the ptient is } \\
\text { directly referred to the clozapine } \\
\text { clinic. The pharmacist who is } \\
\text { responsible for the clinic requests } \\
\text { the blood sample.....The Clinic tea } \\
\text { provides an education on } \\
\text { clozapine to all patients because } \\
\text { the drug causes severe side } \\
\text { effects....and clozapine-induced } \\
\text { agranulocytosis... regular blood test } \\
\text { are important to check the white } \\
\text { blood cells( } 2 \text {. }\end{array}$ \\
\hline
\end{tabular}




\begin{tabular}{|c|c|c|c|}
\hline $\begin{array}{l}\text { Participant } \\
\text { profession }\end{array}$ & $\begin{array}{l}\text { Participant } \\
\text { ID }\end{array}$ & $\begin{array}{l}\text { Subtheme } 1 \text { comments } \\
\text { The role of pharmacists in a } \\
\text { multidisciplinary team }\end{array}$ & $\begin{array}{l}\text { Subtheme } 2 \text { comments } \\
\text { The role of pharmacists in } \\
\text { directly interacting with } \\
\text { patients }\end{array}$ \\
\hline & & & $\begin{array}{l}\text { A pharmacist should have a } \\
\text { pharmacy programme even once a } \\
\text { month; a pharmacist should } \\
\text { educate and counsel patients } \\
\text { about all medicine uses. The } \\
\text { pharmacist explains to the patient, } \\
\text { for example, possible side-effects } \\
\text { and the use of the medication (2). } \\
\text { The pharmacist should monitor } \\
\text { patients' responses to medications } \\
\text { and any negative effects of } \\
\text { therapy (2). }\end{array}$ \\
\hline
\end{tabular}

Subtheme 3 comments

The value of clinical pharmacy services in mental health

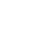

Nurse $4,7,13 \quad$ I hope there is a ward pharmacy in
each ward, and all wards have a
daily pharmacist visit (4).
A pharmacist should review the
patient's medication regimen and
daily progress should be taken into
account with the medical team. A
pharmacist should report and
agree on a medication
management plan and requested
modification and the pharmacist
should inform the physician.
Physician writes a prescription and
medication order review by
pharmacists (4).
Pharmacists should be members of
the healthcare teams, but the
pharmacist should dispense
medications only (7).
Unfortunately, there is no
communication between the
pharmacist and the physician
except through the papers (7).




\begin{tabular}{|c|c|c|c|c|}
\hline $\begin{array}{l}\text { Participant } \\
\text { profession }\end{array}$ & $\begin{array}{l}\text { Participant } \\
\text { ID }\end{array}$ & $\begin{array}{l}\text { Subtheme } 1 \text { comments } \\
\text { The role of pharmacists in a } \\
\text { multidisciplinary team }\end{array}$ & $\begin{array}{l}\text { Subtheme } 2 \text { comments } \\
\text { The role of pharmacists in } \\
\text { directly interacting with } \\
\text { patients }\end{array}$ & $\begin{array}{l}\text { Subtheme } 3 \text { comments } \\
\text { The value of clinical pharmacy } \\
\text { services in mental health }\end{array}$ \\
\hline & & $\begin{array}{l}\text { The pharmacist's intervention is } \\
\text { very important because the } \\
\text { pharmacists are experts of } \\
\text { medicines and are responsible for } \\
\text { pharmacotherapy and nobody, } \\
\text { even physician, knows more about } \\
\text { the medications than the } \\
\text { pharmacist (7). }\end{array}$ & & \\
\hline
\end{tabular}

\section{The role of pharmacists in direct interactions with patients}

Most participants indicated that pharmacists did not provide enough patient education and counselling. Some participants highlighted a lack of communication skills as a hindrance to effective contact between pharmacists and patients, although others felt that this poor level of communication is improving.

Regarding the future role of the pharmacist in patient interactions, most of the participants generally felt that pharmacists should have a more active role in patient care via several different actions: (1) Monitoring drugrelated side effects and educating patients about the safe and appropriate use of medication; (2) Monitoring whether patients are adhering to their drug therapies; (3) Placing pharmacists in outpatient clinics, where they can provide consultations in a private area. This placement will optimise patient care by providing concurrent treatment and counselling; and (4) Routinely counselling and educating patients regarding the safe and appropriate use of medications. However, some controversy regarding the idea of pharmacist counselling still exists because some participants felt that educating patients about the safe and effective use of medication is still the responsibility of the physician/psychiatrist. According to Participant 8 (healthcare administrator): "It should remain the physician's responsibility to counsel patients about prescribed medications".

\section{The value of clinical pharmacy services in mental health}

Most participants felt that the current value of the pharmacist in the clinical healthcare team was limited. On the other hand, others thought that pharmacists do play important clinical roles. They believed that pharmacists could improve the quality of healthcare received by patients, particularly outpatients, by educating them and reducing medical errors. The level of HCPs comfort was significantly higher at Hospital A than Hospitals B and C. For example, Participant 3 (pharmacist) from hospital A described its pharmacy model as follows: "Our clinical pharmacists have work experience but not certificates. They have more than five years of work experience as clinical pharmacists. In my view, the experience is very important". In contrast, Participant 6 (pharmacist) from Hospital B stated: "We do not have a clinical pharmacist. We need a clinical pharmacist who would help us in improving the services provided to the patient." Finally, according to Participant 9, who was from Hospital C: "there is no clinical pharmacy in the hospital".

\section{Perceptions of healthcare professionals and hospital administrators}

Most participants mentioned the negative effect of physicians' attitudes and perceptions toward the role of the pharmacist. According to Participant 3 (pharmacist): "Physicians underestimate a pharmacist's capabilities. In addition, physicians often do not think that a pharmacist can participate in decision-making."

Some physicians believe that a pharmacist should not have a clinical role. Moreover, participants found that older physicians were less accepting of a clinical role for the pharmacist, particularly pharmacists directly participating in patient care. These physicians, in particular, have some difficulties working with pharmacists. Participant 11 (consultant psychiatrist), who had the most years in practice, mentioned that: "this [is the] role of the physician because [the] physician knows the patient before recommending treatment and how to monitor drug therapy...". Some participants thought that another factor behind negative perceptions was that pharmacists themselves did not want to participate in managing patient medication. Participant 5 (specialist psychiatrist) indicated: "It is possible that pharmacist really does not want to participate in the complexity of drug [related decisions], and only [in the] dispensing of medicines".

\section{Lack of pharmacy education and training in mental health}

The majority of participants reported a need to provide psychiatric pharmacists with specialised education and training in mental health. This training would prepare 
them for specific cases and enable them to perform clinical roles. For example, Participant 7 (nurse) recommended continuing education: "there should be courses and training on the role of the pharmacist, and the pharmacist also should take continuing education..."

\section{Shortage of pharmacist staff, clinical pharmacists, and pharmacy resources}

Concerns were raised by participants regarding how a psychiatric pharmacy practice would function within the current healthcare environment, specifically, as stated by Participant 5 (specialist psychiatrist): "The role of the pharmacist in this hospital is still limited due to the shortage of pharmacists." Additionally, not enough psychiatric pharmacists who specialise in mental healthcare are available. Participant 12 (pharmacist) stated: "there is a shortage of pharmacists, and most of the pharmacists are not specialised in mental health". Additional comments by different HCPs are shown in Table II.

Table II: Theme 2 - Barriers to developing the role of pharmacists as members of healthcare teams

\begin{tabular}{|c|c|c|c|c|}
\hline $\begin{array}{l}\text { Participant } \\
\text { profession }\end{array}$ & Participant ID & $\begin{array}{l}\text { Subtheme } 1 \text { comments } \\
\text { Perceptions of other } \\
\text { healthcare professionals } \\
\text { and hospital } \\
\text { administrators }\end{array}$ & $\begin{array}{l}\text { Subtheme } 2 \text { comments } \\
\text { Lack of pharmacy training in } \\
\text { mental health }\end{array}$ & $\begin{array}{l}\text { Subtheme } 3 \\
\text { comments } \\
\text { Shortage of } \\
\text { pharmacist stations, } \\
\text { clinical pharmacists, } \\
\text { and pharmacy } \\
\text { resources }\end{array}$ \\
\hline $\begin{array}{l}\text { Healthcare } \\
\text { administrator }\end{array}$ & 1 & $\begin{array}{l}\text { Physicians and hospital } \\
\text { administrators' attitudes and } \\
\text { perceptions towards the role } \\
\text { of the pharmacist are not } \\
\text { positive (1). } \\
\text { Some pharmacists do not take } \\
\text { time with patients and do not } \\
\text { care whether the patients } \\
\text { take medication as } \\
\text { prescribed...The pharmacist } \\
\text { does not pay full attention to } \\
\text { the patient and does not show } \\
\text { empathy toward patients (1). }\end{array}$ & $\begin{array}{l}\text { Training alone is not enough, and } \\
\text { it should be training and study. The } \\
\text { pharmacist should take } \\
\text { certification in psychiatric } \\
\text { pharmacy (1). }\end{array}$ & \\
\hline Registrar & 14 & $\begin{array}{l}\text { I hope to improve the } \\
\text { collaboration between } \\
\text { pharmacists and physicians in } \\
\text { the future. I would like to see } \\
\text { pharmacists participate in } \\
\text { ward rounds with physicians. } \\
\text { So, the pharmacist would } \\
\text { perform a review of drug } \\
\text { therapy and help us reduce } \\
\text { potential drug interactions } \\
\text { and adverse effects (14). }\end{array}$ & & $\begin{array}{l}\text { Assign administrative } \\
\text { specialists to perform a } \\
\text { wide range of } \\
\text { administrative duties at } \\
\text { the pharmacy. So, the } \\
\text { pharmacists will focus care } \\
\text { on pharmaceutical care } \\
\text { (14). }\end{array}$ \\
\hline Specialist psychiatrist & 5,10 & $\begin{array}{l}\text { It is possible that pharmacist } \\
\text { really does not want to } \\
\text { participate in the complexity } \\
\text { of drug, and only dispensing } \\
\text { of medicines. Pharmacists do } \\
\text { not want to spend time } \\
\text { counselling patients (5). }\end{array}$ & $\begin{array}{l}\text { Pharmacists are very } \\
\text { knowledgeable about drugs more } \\
\text { than physicians and we (physicians) } \\
\text { are not focused on medication in } \\
\text { medical schools. Pharmacy is a } \\
\text { science-based profession and } \\
\text { pharmacy is the science and } \\
\text { technique of dealing with the } \\
\text { medications (5). } \\
\text { We did not have mental health } \\
\text { training for dealing with mentally ill } \\
\text { patients (5). } \\
\text { The pharmacist does not perform } \\
\text { clinical activities during training } \\
\text { courses (10). }\end{array}$ & $\begin{array}{l}\text { The role of the pharmacist } \\
\text { in this hospital is still } \\
\text { limited due to a shortage } \\
\text { of pharmacists (5). }\end{array}$ \\
\hline
\end{tabular}




\begin{tabular}{|c|c|c|c|c|}
\hline $\begin{array}{l}\text { Participant } \\
\text { profession }\end{array}$ & Participant ID & $\begin{array}{l}\text { Subtheme } 1 \text { comments } \\
\text { Perceptions of other } \\
\text { healthcare professionals } \\
\text { and hospital } \\
\text { administrators }\end{array}$ & $\begin{array}{l}\text { Subtheme } 2 \text { comments } \\
\text { Lack of pharmacy training in } \\
\text { mental health }\end{array}$ & $\begin{array}{l}\text { Subtheme } 3 \\
\text { comments } \\
\text { Shortage of } \\
\text { pharmacist stations, } \\
\text { clinical pharmacists, } \\
\text { and pharmacy } \\
\text { resources }\end{array}$ \\
\hline $\begin{array}{l}\text { Specialist clinical } \\
\text { psychologist }\end{array}$ & 2 & $\begin{array}{l}\text { Some physicians believe that } \\
\text { they should write the } \\
\text { prescriptions and the } \\
\text { pharmacist should only } \\
\text { dispense. Some pharmacists } \\
\text { just dispense the medication } \\
\text { without interference to avoid } \\
\text { problems with physicians (2). }\end{array}$ & & \\
\hline Pharmacist & $3,6,12$ & $\begin{array}{l}\text { Physicians underestimate a } \\
\text { pharmacist's capabilities. And } \\
\text { that the physicians often do } \\
\text { not think that a pharmacist } \\
\text { can participate in decision- } \\
\text { making... Physician does not } \\
\text { estimate pharmacists' } \\
\text { interventions (3). } \\
\text { Upon to my knowledge, there } \\
\text { is a difference between } \\
\text { practice and education and } \\
\text { the role of the pharmacist in } \\
\text { mental healthcare is very } \\
\text { difficult (12). }\end{array}$ & $\begin{array}{l}\text { Training pharmacists to become } \\
\text { clinical pharmacists ( } 3 \text { ). } \\
\text { We did not have mental health } \\
\text { training for dealing with mentally ill } \\
\text { patients. Even in the colleges, we } \\
\text { did not deal with psychotropic } \\
\text { drugs because it was closed, and } \\
\text { we were not allowed as students to } \\
\text { deal with psychiatric patients. } \\
\text { There are no training courses in } \\
\text { psychopharmacology (6). } \\
\text { The College of Pharmacists does } \\
\text { not include enough information } \\
\text { about psychiatry across disciplines } \\
\text { (12). }\end{array}$ & $\begin{array}{l}\text { Employing a large number } \\
\text { of pharmacists and prefer } \\
\text { employing clinical } \\
\text { pharmacists as well as } \\
\text { training pharmacists to } \\
\text { become clinical } \\
\text { pharmacists (3). } \\
\text { The shortage of } \\
\text { pharmacists, and. Most } \\
\text { pharmacists are not } \\
\text { specialized in mental } \\
\text { health (12). } \\
\text { The weakness of available } \\
\text { resources and increased } \\
\text { administrative pharmacy } \\
\text { workload, like records and } \\
\text { documentation on } \\
\text { pharmacy (12). }\end{array}$ \\
\hline Nurse & $4,7,13$ & & $\begin{array}{l}\text { Should be courses and training on } \\
\text { the role of the pharmacist, and the } \\
\text { pharmacist should take continuing } \\
\text { education ( } 7) \text {. }\end{array}$ & \\
\hline
\end{tabular}

\section{Development of the pharmacist job description}

Participants felt that a lack of awareness among HCPs regarding the job description and roles and responsibilities of pharmacists has led to negative perceptions toward collaboration between the pharmacist and the healthcare team. Therefore, the participants recommended improving guidelines for the responsibilities of pharmacists in the healthcare system to further develop the pharmacy profession and integrate it into the overall healthcare system of the hospital.

\section{Development of communication skills and collaboration strategies in pharmacy}

The participants further suggested it might be beneficial for pharmacists to develop excellent interpersonal communication skills. A communication strategy should be put in place to build and maintain collaborative relationships. Professional communication and team collaboration should be based on sharing responsibilities between all HCPS, and this cooperation should be formalised with a policy.
Participants suggested developing training programmes in communication skills for both pharmacists and other HCPs to address these issues. In particular, Participant 14 (registrar) stated: "I suggest including communication skills in healthcare curriculum, which should be designed for physicians and healthcare professionals."

\section{Implementation of electronic prescribing}

Participants thought that implementing an electronic prescribing system would improve mental health pharmacy services. They listed several potential advantages of using computer systems, all resulting in reduced prescription errors and thus improving patient safety and patient outcomes, especially in hospitals with limited numbers of pharmacists. It was also felt pharmacists should have access to patient health records and be connected to other hospital systems, which would provide the pharmacist with additional support and resources, especially in a small hospital. Participant 8 (healthcare administrator) stated: "We hope to see electronic prescribing and developments in pharmacy." Additional comments of different HCPs are shown in Table III. 
Table III: Theme 3 - Facilitators of the development of a mental health pharmacy

\begin{tabular}{|c|c|c|c|c|}
\hline $\begin{array}{l}\text { Participant } \\
\text { profession }\end{array}$ & Participant ID & $\begin{array}{l}\text { Subtheme } 1 \text { comments } \\
\text { Implementation of } \\
\text { electronic prescribing }\end{array}$ & $\begin{array}{l}\text { Subtheme } 2 \\
\text { comments } \\
\text { Development of the } \\
\text { job description of } \\
\text { pharmacist }\end{array}$ & $\begin{array}{l}\text { Subtheme } 3 \text { comments } \\
\text { Development of } \\
\text { communication skills and } \\
\text { collaboration strategies } \\
\text { in pharmacy }\end{array}$ \\
\hline $\begin{array}{l}\text { Healthcare } \\
\text { administrator }\end{array}$ & 1,8 & $\begin{array}{l}\text { We hope to see electronic } \\
\text { prescribing and developments in } \\
\text { pharmacy (8). } \\
\text { Electronic prescribing saves the } \\
\text { pharmacist time (8). }\end{array}$ & & $\begin{array}{l}\text { Pharmacists should learn } \\
\text { communication skills and learn } \\
\text { more about how to } \\
\text { communicate with healthcare } \\
\text { workers and patients (1) }\end{array}$ \\
\hline Registrar & 14 & & & $\begin{array}{l}\text { I suggest including } \\
\text { communication skills in the } \\
\text { healthcare curriculum which } \\
\text { should be designed for } \\
\text { physicians and healthcare } \\
\text { professionals.' Such } \\
\text { programmes would help build } \\
\text { an effective working } \\
\text { relationship between } \\
\text { pharmacists and healthcare } \\
\text { professionals (14). }\end{array}$ \\
\hline Specialist psychiatrist & 5,10 & & $\begin{array}{l}\text { Healthcare practitioners } \\
\text { should know the } \\
\text { pharmacist job description. } \\
\text { Pharmacists should know } \\
\text { about their roles and } \\
\text { building and maintaining } \\
\text { patient relationships. The } \\
\text { hospital administration } \\
\text { should establish clear } \\
\text { policies and procedures in } \\
\text { collaboration with the } \\
\text { medical team to identify } \\
\text { the role of the clinical } \\
\text { pharmacists (5). }\end{array}$ & $\begin{array}{l}\text { The pharmacist should share } \\
\text { responsibilities about } \\
\text { medication management and } \\
\text { especially provide medication } \\
\text { management (5). } \\
\text { The pharmacist should have } \\
\text { good communication skills to } \\
\text { connect with the patients (10). } \\
\text { Good communication with the } \\
\text { people who take care of } \\
\text { mentally ill patients would } \\
\text { improve health outcomes (10). } \\
\text { The important thing is good } \\
\text { communication with the } \\
\text { therapeutic team and } \\
\text { continuing about educating } \\
\text { patients and pharmacist talks is } \\
\text { the right way to raise } \\
\text { awareness about medicines on } \\
\text { how to use them appropriately } \\
\text { (14). }\end{array}$ \\
\hline Consultant psychiatrist & 9,11 & & & $\begin{array}{l}\text { Should be good communication } \\
\text { between the pharmacist and } \\
\text { healthcare providers. }\end{array}$ \\
\hline $\begin{array}{l}\text { Specialist clinical } \\
\text { psychologist }\end{array}$ & 2 & & $\begin{array}{l}\text { The role of the pharmacist } \\
\text { has not been clearly } \\
\text { defined ( } 2 \text { ). }\end{array}$ & \\
\hline
\end{tabular}

Pharmacist $\quad 3,6,12$

Computerized warnings and alarms are used to improve safety by alerting to warn of potentially harmful drug-drug interactions either in the pharmacy or in the clinic. So the doctor cannot order them (3) We need pharmacists' electronic access to lab data (6). Using and activation of a hospital electronic prescribing (EP) systems to review all patients' medications and connect with other non-psychiatric hospitals (6). 


\begin{tabular}{|c|c|c|c|c|}
\hline $\begin{array}{l}\text { Participant } \\
\text { profession }\end{array}$ & Participant ID & $\begin{array}{l}\text { Subtheme } 1 \text { comments } \\
\text { Implementation of } \\
\text { electronic prescribing }\end{array}$ & $\begin{array}{l}\text { Subtheme } 2 \\
\text { comments } \\
\text { Development of the } \\
\text { job description of } \\
\text { pharmacist }\end{array}$ & $\begin{array}{l}\text { Subtheme } 3 \text { comments } \\
\text { Development of } \\
\text { communication skills and } \\
\text { collaboration strategies } \\
\text { in pharmacy }\end{array}$ \\
\hline Nurse & $4,7,13$ & $\begin{array}{l}\text { because computerised pharmacy } \\
\text { systems. So, a pharmacist can } \\
\text { review all orders entered into } \\
\text { the hospital (4). }\end{array}$ & $\begin{array}{l}\text { The key point is that a } \\
\text { pharmacist clinical practice } \\
\text { guideline should be part of } \\
\text { the policy and procedure } \\
\text { applied at the hospital in } \\
\text { order to involving } \\
\text { pharmacists as a crucial } \\
\text { members of the treatment } \\
\text { teams in healthcare (4). } \\
\text { The Problem is in the } \\
\text { effective distribution of } \\
\text { roles and responsibilities } \\
\text { (13). }\end{array}$ & \\
\hline
\end{tabular}

\section{Discussion}

This study is the first qualitative study that focuses on pharmacy services in mental health hospitals across Saudi Arabia to explore how pharmacists are perceived as part of the medical team. Consistent with previous research, HCPs showed familiarity with traditional pharmacist roles, including providing information, dispensing medications, compounding, and educating patients about safe and appropriate medication use (Mohiuddin et al., 2019). However, many participants were reluctant to acknowledge pharmacists as specialised mental health medication providers. Some HCPs have reported that pharmacists lack the knowledge to participate in clinical decisions, similar to previous findings (Mekonnen et al., 2018; Tahaineh et al., 2019). Participants also reported poor communication and a lack of collaboration and teamwork between HCPs and pharmacists. They considered that pharmacist roles are limited to preparing and dispensing drugs mainly. However, pharmacist duties have recently evolved from compounding and dispensing to providing patient care, which are changes appreciated by HCPs (Bollen et al., 2018).

In the current study, HCPs were receptive to pharmacists directly providing patient care, such as designing therapies, monitoring responses to drugs, and educating patients about the appropriate use of medicines. These results were consistent with previous findings (Goldstone et al., 2015; Kempen et al., 2020). For example, a quantitative study on psychiatrists' perceptions and expectations of clinical pharmacists in a healthcare team found that psychiatrists in Saudi Arabia were receptive to many elements of patientcentred pharmaceutical care, such as counselling, costeffective alternative education, and therapeutic value for drugs (Almazrou et al., 2015). Furthermore, clinical pharmacy services are beneficial, and HCPs expect pharmacists to play a leading role in direct patient care, especially supporting treatment and educating and counselling patients (Goldstone et al., 2015; AbdelLatif, 2016). While dealing with patients, pharmacists must also consider the requirements of a patientcentred healthcare model. Improved healthcare is linked to efficient interactions between patients and pharmacists (Mohiuddin et al., 2019).

The participants in this study expressed concerns regarding communication gaps between pharmacists and HCPs, perhaps attributed to the fact that HCPs rarely interact with pharmacists, causing physicians to be reluctant to accept more clinical roles for pharmacists. This finding is consistent with those of previous studies (Almazrou et al., 2015; Mekonnen et al., 2018; Mohiuddin et al., 2019). Participants highlighted a lack of physician-pharmacist collaboration, noting the insufficient number of pharmacists in hospital wards. It was reported that physicians rarely encounter pharmacists performing patient care services and that physicians would indeed appreciate more frequent physician-pharmacist interactions, supporting the fact that interprofessional learning and interdisciplinary work can increase understanding among HCPS (Kempen et al., 2020).

This study suggests that pharmacists should become more involved in both direct and team-based patient care to improve HCP-pharmacist relationships and resolve problems originating from poor communication between HCPs and pharmacists. This finding is consistent with other results that encourage pharmacists to provide direct pharmaceutical services to patients instead of focusing on medication administration records to ensure adequate patient care and avoid drug-related problems (Mohiuddin et al., 2019). The interviewees suggested the development of interprofessional education programmes to establish 
communication strategies and collaborations between HCPs and pharmacists.

This study identified several factors affecting the interactions between pharmacists and HCPs. One of the main factors affecting these interactions was found to be linked to the traditionally hierarchical nature of the HCP team, pharmacist conflict of interest with other HCPs, role definition, the synergy between team members, and the opinion of members regarding the efficacy of the interaction. Interactions between pharmacists and physicians are affected by their wish for collaboration, which is influenced by their views about the benefits of such interactions (Alaqeel \& Abanmy, 2015; Kempen et al., 2020). Physicians showed generally negative attitudes towards the extended roles of pharmacists in mental healthcare. Although their attitudes towards and acceptance of pharmacists' clinical services have improved over time, physicians feel that their professional role is inappropriately challenged during interactions with pharmacists (El Hajj et al., 2016). Historically, physicians have had complete responsibility for decisions concerning patient care (Mohiuddin et al., 2019). Physicians' acceptance of clinical pharmacist services is related to physicians' exposure to pharmacists in addition to the individual receptiveness to consultative and educational services provided by pharmacists (Abdel-Latif, 2016). Interactions between physicians and pharmacists were found to correlate with positive attitudes towards the pharmacy profession in mental health in Saudi Arabia (Alaqeel \& Abanmy, 2015).

This study demonstrated that pharmacists are poorly educated in terms of mental health work, perhaps because pharmacy colleges cannot provide the necessary mental health education. Psychiatry is taught based on therapeutics, and very few institutions provide internships in psychiatry, especially for pharmacists.

Plans are ongoing in Saudi Arabia to standardise and expand mental health services across the nation and develop specialised training programmes for every sector of mental health services (Koenig et al., 2014). In recent years, progress has been made in several areas of the mental health system. The Health Sector Transformation Strategy aims to establish a comprehensive health system designed to assist people with their health and mental health well-being needs (Health Sector Transformation Strategy, 2017). As a result of these changes, improvements in the delivery of mental health services have started to occur in Saudi Arabia (Qureshi, AlHabeeb \& Koenig, 2013).

\section{Strengths and limitations}

This study used convenience sampling, which was not stratified according to participant professions. Several hospitals from three regions were included, but not from all Saudi Arabia, with most HCPs and managers working in different settings. Thus, extending the results to other hospitals should be undertaken with caution. Furthermore, the study only included HCPs in working governmental hospitals only. Finally, responses were voluntary; possibly only HCPs interested in pharmacist services participated. Further quantitative studies that cover a larger area of Saudi Arabia are recommended.

The use of open-ended questions allowed participants to share their views and experiences freely; they frequently referred to previous experiences. Interviews were conducted by a senior clinical pharmacist, and thus participants might have felt uncomfortable expressing views that could be perceived as negative towards pharmacists. The same author conducted interviews and analysed the data, which may lead to interpretation bias. Nevertheless, this approach allowed the researcher to take advantage of nonverbal information expressed during interviews. There were challenges regarding language [interviewees 6,7]. The interviews were conducted in Arabic and reported in English. Considering the purpose of the study was to convey participant views, this could be difficult when quotes supposed to support the findings have to be translated, as their meanings may be lost in translation.

\section{Impact of findings on practice}

The findings show that improved communication will increase the visibility of pharmacists. HCPs recommend changes to medical and pharmacy student curricula, encouraging interprofessional education through simulated patient settings, organisation of workshops and education seminars, and teaching roles of HCPs in patient care. Future studies should focus on methods for expanding clinical pharmacy services in mental hospitals.

\section{Conclusion}

In conclusion, the changing role of the pharmacist is accepted by some HCPs but challenged by others. Change is inevitable, and despite opposition from physicians mainly, it appears that the role of the pharmacist in providing "non-traditional" services is evolving in Saudi mental health facilities in Saudi Arabia. 


\section{Acknowledgement}

This proposal would not have been completed without the help of many people. The author wishes to express thanks especially to Dr lan Maidment, Senior Lecturer in Clinical Pharmacy, Aston University, for his great assistance, patience, and support during this research.

\section{Conflict of interest}

The author declares no conflict of interest.

\section{Source of funding}

The author did not receive any funding.

\section{References}

Abdel-Latif, M. (2016). Hospital doctors' views of, collaborations with and expectations of clinical pharmacists. European Journal of Hospital Pharmacy, 24(6), 343-348. https://doi.org/10.1136/ejhpharm-2016-001075

Alaqeel, S., \& Abanmy, N. (2015). Counselling practices in community pharmacies in Riyadh, Saudi Arabia: a crosssectional study. BMC Health Services Research, 15(1). https://doi.org/10.1186/s12913-015-1220-6

Alipour, F., Peiravian, F., \& Mehralian, G. (2018). Perceptions, experiences and expectations of physicians regarding the role of pharmacists in low-income and middleincome countries: the case of Tehran hospital settings. BMJ Open, 8(2), e019237. https://doi.org/10.1136/bmjopen2017-019237

Almazrou, S., Alnaim, L., \& Al-Kofide, H. (2015). Perceptions, Expectations and Barriers of Physicians towards Working with Clinical Pharmacists in Saudi Arabia. Journal of Scientific Research and Reports, 6(5), 404-415. https://doi.org/10.9734/JSRR/2015/11637

Bollen, A., Harrison, R., Aslani, P., \& van Haastregt, J. (2018). Factors influencing interprofessional collaboration between community pharmacists and general practitioners $-\mathrm{A}$ systematic review. Health \& Social Care in the Community, 27(4). https://doi.org/10.1111/hsc.12705

Çelik, H., Baykal, N., \& Memur, H. (2020). Qualitative Data Analysis and Fundamental Principles. Journal of Qualitative Research in Education, 8(1), 379-406.

https://doi.org/10.14689/issn.2148-2624.1.8c.1s.16m

Charlson, F., van Ommeren, M., Flaxman, A., Cornett, J., Whiteford, H., \& Saxena, S. (2019). New WHO prevalence estimates of mental disorders in conflict settings: a systematic review and meta-analysis. The Lancet, 394(10194), 240-248. https://doi.org/10.1016/S01406736(19)30934-1
Cristancho, S., Goldszmidt, M., Lingard, L., \& Watling, C. (2018). Qualitative research essentials for medical education. Singapore Medical Journal, 59(12), 622-627. https://doi.org/10.11622/smedj.2018093

El Hajj, M., AL-Saeed, H., \& Khaja, M. (2016). Qatar pharmacists' understanding, attitudes, practice and perceived barriers related to providing pharmaceutical care. International Journal of Clinical Pharmacy, 38(2), 330-343. https://doi.org/10.1007/s11096-016-0246-0

Goldstone, L., DiPaula, B., Caballero, J., Park, S., Price, C., \& Slater, M. (2015). Improving medication-related outcomes for patients with psychiatric and neurologic disorders: Value of psychiatric pharmacists as part of the health care team. Mental Health Clinician, 5(1), 1-28.

https://doi.org/10.9740/mhc.2015.01.001

Grossoehme, D. (2014). Overview of Qualitative Research. Journal of Health Care Chaplaincy, 20(3), 109-122. https://doi.org/10.1080/08854726.2014.925660

Hadi, M., \& José Closs, S. (2015). Ensuring rigour and trustworthiness of qualitative research in clinical pharmacy. International Journal of Clinical Pharmacy, 8(3):641-6 https://doi.org/10.1007/s11096-015-0237-6

Health Sector Transformation Strategy. (2017). Retrieved 4 December 2021, from

https://www.moh.gov.sa/en/Ministry/vro/Documents/Heal thcare-Transformation-Strategy.pdf

Kempen, T., Kälvemark, A., Sawires, M., Stewart, D., \& Gillespie, U. (2020). Facilitators and barriers for performing comprehensive medication reviews and follow-up by multiprofessional teams in older hospitalised patients. European Journal of Clinical Pharmacology, 76(6), 775-784. https://doi.org/10.1007/s00228-020-02846-8

Khan, N., McGarry, K., Naqvi, A., \& Holden, K. (2020). Doctors' perceptions, expectations and experience regarding the role of pharmacist in hospital settings of Pakistan. International Journal of Clinical Pharmacy, 42(2), 549-566. https://doi.org/10.1007/s11096-020-00991-9

Koenig, H., Al Zaben, F., Sehlo, M., Khalifa, D., Al Ahwal, M., Qureshi, N., \& AlHabeeb, A. (2014). Mental Health Care in Saudi Arabia: Past, Present, and Future. Open Journal of Psychiatry, 04(02), 113-130. https://doi.org/10.4236/ojpsych.2014.42016

Lawrence, D., Hancock, K., \& Kisely, S. (2013). The gap in life expectancy from preventable physical illness in psychiatric patients in Western Australia: retrospective analysis of population based registers. BMJ (Clinical research ed.), 346, f2539. https://doi.org/10.1136/bmj.f2539

McLeod, M., Karampatakis, G., Heyligen, L., McGinley, A., \& Franklin, B. (2019). The impact of implementing a hospital electronic prescribing and administration system on clinical pharmacists' activities - a mixed methods study. BMC Health Services Research, 19(1). https://doi.org/10.1186/s12913019-3986-4

Mekonnen, A., McLachlan, A., Brien, J., Mekonnen, D., \& Abay, Z. (2018). Barriers and facilitators to hospital pharmacists' engagement in medication safety activities: a qualitative study using the theoretical domains framework. 
Journal of Pharmaceutical Policy and Practice, 11(1). https://doi.org/10.1186/s40545-018-0129-y

Mohiuddin, A. (2019). Psychiatric Pharmacy: New Role of Pharmacists in Mental Health. Scholarly Journal of Psychology and Behavioral Sciences, 2(4). https://doi.org/10.32474/SJPBS.2019.02.000144

Qureshi, N., AlHabeeb, \& Koenig, H. (2013). Mental health system in Saudi Arabia: an overview. Neuropsychiatric disease and treatment, 9, 1121-1135. https://doi.org/10.2147/NDT.S48782

Rotta, I., Salgado, T., Silva, M., Correr, C., \& FernandezLlimos, F. (2015). Effectiveness of clinical pharmacy services: an overview of systematic reviews (2000-2010). International Journal of Clinical Pharmacy, 37(5), 687-697. https://doi.org/10.1007/s11096-015-0137-9

Sabry, N., \& Farid, S. (2014). The role of clinical pharmacists as perceived by Egyptian physicians. International Journal of Pharmacy Practice, 22(5), 354-359.

https://doi.org/10.1111/ijpp.12087

Shahab, M., Al-Tuwaijri, F., Bilal, L., Hyder, S., Al-Habeeb, A., \& Al-Subaie, A. et al. (2017). The Saudi National Mental Health Survey: Methodological and logistical challenges from the pilot study. International Journal of Methods in Psychiatric Research, 26(3).

https://doi.org/10.1002/mpr.1565

Son, D., Kawamura, K., Nakashima, M., \& Utsumi, M. (2015). The Pharmacist-Physician Collaboration for IPW: From Physician's Perspective. Yakugaku Zasshi, 135(1), 109-115. https://doi.org/10.1248/yakushi.14-00222-1

Tahaineh, L., Wazaify, M., Alomoush, F., Nasser, S., Alrawashdh, N., \& Abraham, I. (2019). Physicians' perceptions, expectations, and experiences of clinical pharmacists in Jordan-2017. International Journal of Clinical Pharmacy, 41(5), 1193-1201.

https://doi.org/10.1007/s11096-019-00884-6

Tong, A., Sainsbury, P., \& Craig, J. (2007). Consolidated criteria for reporting qualitative research (COREQ): a 32 item checklist for interviews and focus groups. International Journal for Quality in Health Care, 19(6), 349-357.

https://doi.org/10.1093/intghc/mzm042

Vermeulen, K., van Doormaal, J., Zaal, R., Mol, P., Lenderink, A., \& Haaijer-Ruskamp, F. et al. (2014). Cost-effectiveness of an electronic medication ordering system (CPOE/CDSS) in hospitalized patients. International Journal of Medical Informatics, 83(8), 572-580.

https://doi.org/10.1016/j.ijmedinf.2014.05.003 